\title{
China and Shanghai Cooperation Organization (SCO): Belt and Road Initiative (BRI) Perspectives
}

\author{
Abdul Rab, He Zhilong \\ School of History and Civilization \\ Shaanxi Normal University \\ Chang'an Campus: No. 620, Xian \\ China
}

\begin{abstract}
Shanghai Cooperation Organization (SCO) has been emerging an important regional and international organization since its inception in 2001. The People's Republic of China and the Russian Federation are key members of the organization. Xi Jinping's "The Belt and Road Initiative (BRI)" was supported by all member states of the SCO. The organization constantly provided a favorable number of opportunities for China in the field of economics and trade, energy, culture, and foreign policy. The development steps through the SCO are highly significant for China, thereby the organization's cooperation mechanism is strengthening the ratio of economic achievementof China in the region. This study highlights China's Belt and Road Initiative (BRI)expansionand its optimistic perspectives under the banner of the SCO.
\end{abstract}

Keywords: Shanghai Cooperation Organization, China, Belt Road Initiative, Central Asia, regional connectivity, energy cooperation

The Shanghai Cooperation Organization (SCO) has become an important and attractive organization since it started in 2001. This young organization showed not only constant advancement in regional and international cooperation but also continuous development in China's national interest perspectives. In 2015, the SCO led its 14th Summit of the Council of Heads of Government in Zhengzhou, China; in this summit, the member countries emphasizes the regional economic development through mutual cooperation, which is vital for the Belt Road Initiative (BRI) (Zhengzhou Summit, 2015). Moreover, in Qingdao declaration, the SCO member countries showed the importance of mutual cooperation in the regional economy by promoting transportation, enhancing transits, developing rail and road networks, and upgrading international transport routes. In this context, theystressed the implementationof intergovernmental agreement on "international road transportation facilitation" of 2014summit (Qingdao Declaration, 2018). More importantly, BRI's five goals visibly supporting the regional economic development and expansion of the transit and routes networks in the region (Ghiasy, R. \& Zhou, J., 2017). SCO members confirmed their full support for China's "Silk Road Economic Belt" in their meetings, which is a very essential for Beijing, because the BRI will begin from the neighboring countries of China (Xue Gong, 2018). Such statementsthrough SCO platform will confidently make a progressive results as well as a vocal voice for BRI. Nearly five months before the Zhengzhou summit, heads of SCO member countries gathered in the Ufa Summit on July 10, 2015. In this summit, heads of SCO's member countries passed a historic declaration by approving India and Pakistan (Abdul Rab \& He Zhilong, 2018) as permanent members along with Belarus and Azerbaijan as observer countries and dialogue partners of the SCO. This continuous expansion of the organization places the SCO on top of the world in terms of population and more.

The SCO's support and endeavors in the context of the BRI will play a progressive role in the global and regional levels, especially for China. It also provides the necessary development and strengthening of China's infrastructure projects of the BRI in the region. The present study pursues China's BRI implications under the framework of SCO. To further explore the opportunities for China's BRI under the platform of the SCO, this paper is divided into three parts. The first part highlights the importance of China's proximity with SCO member countries in the perspective of BRI and China's opening of borders with Eurasian land. The second part emphasizes the enchaining economic opportunities of BRI under the framework of the SCO. The third part discusses China's holding influence in energy and strategic policies in the SCO for BRI viewpoints. Finally, this paper concludes with opportunities for China's BRI through the broadenedand multilateral cooperation with the SCO platform.

\section{China's geostrategic position and opening up of border areas:}

The birth of the SCO has a special historical background. The disintegration of the Soviet Union changed the pattern of the world order after the end of the Cold War (Baizakova, K. I., 2013). 
Under the new international situation, China has quickly accelerated its border demarcation work with Russia, Kazakhstan, Kyrgyzstan, Tajikistan, and other countries. The parties have achieved their initial mutual trust and have struggled to pass military negotiations in the border regions (Jing-Dong Yuan, 2010). With the changes in the world order, the abovementioned countries have further initiated security cooperation and formed a fixed dialogue mechanism in 1996 and 1997 by signing two agreements on confidence building in the military field and reduction in military forces in the border areas (Majid, A., 2016). These agreements has been a remarkable diplomatic achievement for China with regard to Xinjiang Uygur Autonomous Region's security perspective through Shanghai Five (forerunner of the SCO). During the downfall of the Soviet Union, East Turkestan Islamic Movement (ETIM) has levitated their separatist movement against the Chinese administration and has sought support from radical Islamic groups of Central Asian countries (Huasheng, Z., 2013). More importantly, SCO established a permanent Regional Anti-Terrorist Structure (RATS) in Tashkent in 2004 (Cabestan, J., 2013) and subsequently signed a series of treaties to combat "three evils" (i.e., terrorism, extremism, and separatism). Thus, the RATS was great achievement for China through the SCO framework and an example of the mutual cooperation of the SCO against the "three evils." On this basis, China availed full opportunity to secure and defeat the ETIM through the mutual cooperation of the SCO.

According to the Library of Congress Federal Division Research, People's Republic of China has 22,117 km land boundaries with 14 neighboring nations(Library of Congress, 2006). Furthermore, a majority of China's neighbors are members and observer states of the SCO; these neighbors include Russia, Kazakhstan, Kyrgyzstan, Tajikistan, Pakistan, India, Mongolia, and Afghanistan. The western and southwestern parts of China are vast and rich in resources but have been extensively underdeveloped. Thus, the core objective of the BRI is socioeconomic and infrastructural development in these parts of China. According to Baogang He (2018), underdevelopment and poverty sparked the ethnic separatist movement and Islamic radicalism in the Xinjiang Province. Moreover, given military demarcation areas, security buffer zones, ethnic subdivisions, and distance from the central city and Deng Xiaoping's eastern coastal economic development, the western parts of China are relatively marginalized.

The geographically adjacent border of China with SCO member countries, such as Manzhouli, Erlian, Alashankou, Khorgos, and other key border cities, has been playing a valuable role in transshipping port city and international logistic cooperation in recent years. This adjacent connection is facilitating bulks of opportunities in socioeconomic development and eradicating poverty in the SCO member countries. The only cross-border economic cooperation zone is located in Khorgos on the Sino-Kazakh border. The Khogros currently becomes the symbol of the deepening relationship of Sino-Kazakh in the region. Furthermore, China's 13th Five-Year Plan outline (Xinhuanet, 2015) also clarifies the construction of the SCO International Logistics Park and the Sino-Kazakhstan Logistics Cooperation Base (China Daily, 2015). In the past years, SCO has passed many statements in their summits for developing the transportation facilities and establishing the international logistics stations in the border areas of the SCO member countries.Henceforth, China's geographical connectivity under the umbrella of SCO, enhancing her economic role in the region.With this regard, Beijing aims to accelerate the economic activities of port cities, cross-border tourism, as well as interconnection through infrastructure construction in these border areas, and form continuous development waves in the western part through infrastructure projects. This situation will offer an opportunity for China to work with the SCO countries to accelerate the transportation and logistics stations for regional connectivity. The progressive work under SCO's framework will further boost the interregional connectivity of China's BRI.

In BRI's six corridors, almost all member countries of the SCO, including observer states, are participating and signed agreements with China. As previously mentioned, Chinese policymakers elucidated that BRI's main objective is regional economic connectivity and improvement of its domestic development. Moreover, the SCO aims and objectives also encouraging the regional economic development and cooperation (Carroll, W. E., 2011). Thus, SCO will play the role of multilateral cooperation and accelerate the "Silk Road Economic Belt." China's close neighborliness policy has earned her significant trust from itsneighbor states. Central Asian region is very important for China's BRI perspectives because it provides access to Europe. Furthermore, two economic corridors (i.e., China-Central Asia-West Asia economic corridor and New Eurasia Land Bridge Economic corridor) are crossing through Central Asia regions. Moscow's support and participation in BRI also encouraging other regional countries because Russia is vital country in the region especially in geo-political and geo-economic perspectives. However, India has many concerns over Beijing's BRI, here, Russia can reduces India's concerns through dialogues because both countries are close and strategic partners. Through the SCO forum, removing the misunderstanding and fear of other countries is easy for China. Furthermore, China Pakistan Economic Corridor (CPEC) is adding significance to China's BRI. Pakistan is also supporting BRI in every forum and has a keen interest in inviting other regional countries in the CPEC. Pakistan is a leading country in the Muslim world and can convince other Gulf oil-rich countries by inviting them for participation in the CPEC. Therefore, the SCO will play an increasingly essential role in China's BRI and accelerate the multilateral cooperation of "Silk Road Economic Belt." 


\section{SCO's economic and trade cooperation and China:}

The beginning journey of SCO was marked by border dialogue and security cooperation among member countries, although, with the passage of time, the SCO has endeavored to pursue economic and trade cooperation within organization (Fei, G., 2010). Economic and trade developments are major entreaty and cooperation lines of the SCO countries. The SCO countries are rich in resources and diverse in culture. According to Matthew Brummer (2007), SCO member countries including Iran (Observer state)containing approximately 50\% of the world's natural gas reserves. In addition, they have considerable differences in terms of development level, economic structure, resource abundance, population density, and consumption habits. Therefore, a huge gap of economic and trade is still exitingas well as a large space is available for industrial cooperation. The structural advantages of multilateral economic and trade cooperation are also prominent within organization. China's BRI infrastructure projects are already in their final stages in the Central Asia countries and these projects will further encourage the economic activities in the region under the SCO framework.

The SCO clearly specified its aims and objectives; "encouraging effective cooperation in trade, economic, scientific technology, energy, and other fields" in its Shanghai Summit in 2001. With this goal, the SCO initiated trade and investment facilitation processes and environment to start the free flow of goods, capital, services, and technology agreements. Since then, the SCO had continuously strengthened multilateral economic and trade cooperation through frequently signed documents and promoted economic and trade cooperation for creating a peaceful and prosperous development in the region. In the joint communique of Beijing Summit in September 2003, the head of states of SCO member countries implemented the plans of multilateral trade and economic cooperation among the SCO member countries (joint communique, 2003). In 2004, SCO countries focused on regional economic cooperation and promoted energy, transportation, telecommunications, and agricultural projects. The multilateral economic and trade cooperation program was approved and implemented in Bishkek summit in 2004, including 127 projects in 11 different areas (joint communique, 2004). After pressing the accelerator on economic activities, the SCO established the SCO Business Council and Interbank Association in the Astana Summit in 2005. In 2007, at the SCO Summit, numerous consensuses were reached on improving the trade and investment environment, promoting the implementation of network projects, and broadening of financing channels. Moreover, the SCO broadened its economic activities with other regional organizations such as the Eurasia Economic Cooperation (EEC), CIS, and ASEAN. Besides, to handle the financial crisis and accelerate its economic development, the SCO strengthened its internal coordination and conducted in-depth regional financial cooperation.

Since the BRI was implemented, the SCO countries had shown considerable interest in cooperating with China. The scale of economic and trade cooperation between China and the SCO countries had continued to increase from US $\$ 129.4$ billion in 2013 to US $\$ 217.6$ billion in 2017, a massive increase in comparison with US\$12 billion in 2001 (Zhong Nan \& Jing Shuiyu, 2018). China's investment in the SCO member countries has exceeded US\$70 billion. With the continuous advancement in the BRI, the economic and trade cooperation is also deepening among the SCO member countries. In 2014, at the SCO's Dushanbe Summit Declaration, the head of member countries stated that "the top priority of the SCO is to facilitate favorable environments through strengthening the economic and trade events, improvements of technology and industrial sector and set-up of the transport and logistics development among the SCO member countries" (Dushanbe Declaration, 2014). Russia also appreciated and showed complete support for Xi Jinping's BRI. On June 20, 2015, Russian President Vladimir Putin said that Russia and China are committed to "docking" the development strategy of the Eurasian Economic Union with the Silk Road Economic Belt, which will bring huge development opportunities to both sides and also in the regions (China Daily, 2015). The abovementioned facts sufficiently confirm the characteristics of the synergy between the SCO's member countries and China's BRI.

Moreover, Beijing's "Westward Opening" and Moscow's "Look East" policies further consolidate their strategic understanding developments. Russia is animportant partner of China because the former provides a security facilities in the Central Asian Region, which is very essential for Xi Jinping's proposed Silk Road Economic Belt's success. Thus, the SCO platform will accomplish China's economic dream through SCO's mutual trust and cooperation. The BRI has created additional opportunities for multilateral economic cooperation development within SCO, which is convenient for understanding each other's interests. Nevertheless, the SCO provides a safe regional environment for broadening the BRI for China and also developing mechanisms and platforms for cooperation and exchange of opinions in the regional level.

China's BRI is connecting 65 countries through six economic corridors across the three continents of Asia, Europe, and Africa, thus covering nearly $70 \%$ of the world's population (Zhou, W. \& Esteban, M., 2018). Except for "ChinaIndochina Peninsula Economic Corridor," the five other major corridors are passing through the SCO member countries. 
With this development, the SCO forum provide many opportunities for China in the "economic corridor" expansion. It is foreseeable that the SCO countries will continue to expand its integrated regional markets for the BRI and open their borders for economic and trade activities and for further strengthen the regional connectivity.

\section{SCO and China's strategic and energy policy:}

The SCO had continuously consolidated its consensus and expanded its membership from Eurasian region to South Asia. In the Tashkent Summit in June 2010, the SCO's Heads of State Council approved the "SCO to Accepting New Member Regulations" (Tashkent Summit, 2010). Thus, for the first time, in the Ufa Summit 2015, the SCO permitted India and Pakistanas a full membership. Currently, Mongolia, Iran, Afghanistan, and Belarus are observer countries, whereas Sri Lanka, Turkey, Azerbaijan, Armenia, Cambodia, and Nepal are dialogue partners of the SCO. According to a scholar, with eight permanent members, the SCO covers $80 \%$ of Eurasian land, which is approximately half of the world's population and a quarter of the whole world's GDP (Strategic comments, 2018). The SCO has become a swiftly expanding international organization and has played an increasingly key role in regional and international affairs. With this regard, China has a huge opportunity to accelerate her strategic adjustment and developments in the region as well as work for BRI for a long term under the flagship of the SCO.

US President Donald Trump has created complicated relationship with Beijing after declaring a trade war by imposing a huge sum of tariff tax on China's goods. The policy of Trump's trade war will create further hurdles for China in terms of Chinese commodity tariff rate and RMB exchange rate and will also challenge Sino-US economic and trade exchanges. In addition, Russia has also been subjected to sanctions by Europe and the United States since the Ukrainian crisis. China and Russia are determined to continue expanding their strategic cooperation through the SCO forum. With the expansion of the SCO and the promotion of the BRI, Beijing's strategic measures could be active and continue to accelerate new developments in the hinterlands of Central and West Asia.

Furthermore, in terms of the energy sector, the SCO provides a golden opportunity for China through SCO's "Energy Club." Galiia A. Movkebaeva (2013) stated that "China, Kazakhstan, and Russia are making progress in energy cooperation, but so far largely on the basis of bilateral agreements, the SCO Energy club offers opportunities to expand that cooperation in a way that benefits all the organization's members and observer states." According to Khalid Rahman (2011), Kazakhstan contains 30 billion barrels of oil reserves, making largest countryin oil production in Central Asia and also contains 2.4 trillion cubic meters of gas reserves. Uzbekistan's total gas reserves are nearly 1.8 trillioncubic meters. Turkmenistan (a dialogue partner state of the SCO) is the world's fourth largest country that contains 7.94 trillion cubic meters natural gas reserves (Rahman, K., 2011). Moreover, SCO including with Iran (observer country of SCO) containing about $50 \%$ of total world's natural gas reserves and $18 \%$ of the world's proven oil reserves (Brummer, M., 2007). Thus, to push the accelerator in energy activity, the SCO held several meetings and emphasized to strengthen energy cooperation and ensure energy security with the leaders of the SCO. In 2006, at the SCO Summit, Russian President Vladimir Putin suggested the establishment of SCO Energy Club for strengthening the energy cooperation among the member states, this proposal was supported by all SCO member countries (Galiia A. Movkebaeva, 2013).That is why China is strongly attached to the importance of energy strategy under the framework of SCO. More significantly, Central Asian's rich natural resources provide an alternative passage to China in Malacca Strait. Under the SCO's "Energy Club," it is foreseeable that,Beijing cut its half of oil import from the Middle East in the future. This measure is vital for China's gigantic networks of BRI. Thus, SCO platform provides the People's Republic of China to maintain her firm cooperation with Russia, Kazakhstan, and other Central Asian countries in the energy sector. Beijing had signed numerous gas and oil pipeline projects with Russia, Kazakhstan, and Turkmenistan (Turkmenistan is not a permanent member of the SCO).

In May 2014, China and Russia signed the natural gas purchase and sales contract with a cumulative contract period of 30 years and a total amount of USD 400 billion. The contract states that Moscow will supply gas amounting to 38 billion cubic meters to Beijing annually for 30 years (Galiia A. Movkebaeva, 2013). The Sino-Russian East Line natural gas pipeline is under construction and will be completed in 2020. This project is considered one of China's largest gas pipeline projects that start from Russia and end in Shanghai, passing through eight Chinese regions that cover a total of 3,371 km (China Daily, 2017).Moreover, China signed agreements with Turkmenistan on importing gas in 2006 and started constructing gas pipelines in 2009. To increase her gas import quantity from Turkmenistan, China invested in one of the largest gas pipeline systems in the world (Fei, G., 2010). The China-Central Asia gas pipeline runs from Turkmenistan, Uzbekistan, and Kazakhstan to China, covering a route of approximately $1,830 \mathrm{~km}$ (FarkhodAminjonov, 2018). This gas pipeline is constructed into four lines: A, B, and C, D, and the annual gas transmission from Turkmenistan to China can reach 25 billion cubic meters to 30 billion cubic meters (FarkhodAminjonov, 2018). 
At present, China is operating Gwadar Deep Sea Port located in Pakistan. China Pakistan Economic Corridor (CPEC) start from Khasgir city of China's Xinjiang and end at Gwadar deep sea port, south of Pakistan, means CPEC providing access of Indian Ocean through Gwadar deep seaport to China.The geographical location of Gwadar Deep Sea Port is important and far-reaching for China and for BRI perspectives (Qian, X., 2016) because it not only shortens China's transportation routes but also reduces China's dependence on the Malacca Strait (Qian, X., 2016). China has also invested in Zarubino Port with Russian cooperation. Zarubino Port is located in Russia, which is very close to China and North Korea, that is, only $18 \mathrm{~km}$ away from China (Johannes Feige, 2016). It is said that Zarubino port has a capacity of handling about 60 million tons of cargo and considering one of biggest port in northeast Asia (China Daily, 2015). The People's Republic of China could avail the SCO's expansion opportunities and conduct strategic research and design for the long-term interests of the BRI and also endeavor for additional strategic development and regional connectivity under the SCO framework.

\section{Conclusion}

China's ambitious BRI is definitely a single massive foreign policy program in the entire history of China. The BRI's gigantic network connectivity will make regional countries closer to each other through enhancing economic and trade cooperation, sharing culture and people-to-people contact, and supporting a peaceful and prosperous environment. The SCO platform will provide numerous opportunities for China to accelerate the planning mechanism of the BRI. China can rebuild its security, economic and foreign policies regarding to BRI perspectives, under the banner of the SCO. The Beijing's BRI will provide a favorable opportunity to create a grand regional connectivity by using the SCO's platform as well as influence in its bilateral and multilateral relations. Furthermore, the SCO's support for the BRI and China's geographical proximity with Central Asian States, India, Russia, and Pakistan will promote openness, regional connectivity, and cross-border transportation in a huge and profound level. Together with the SCO member countries, China will constantly enrich and improve the cooperation content and methods of the BRI and actively cooperate with the national development and regional cooperation plans. Cooperative research, exhibition forums, trainings, and official exchange visits of the SCO member countries will further encouraged their understanding and recognition of the connotation, goals, and tasks of the BRI. Finally, the SCO member countries are acknowledging the China's new vision and new pattern of economic development regarding economic and trade enlargement, regional connectivity perspectives and jointly endeavor for the economic development and regional progress for prosperous and peaceful region.

\section{Acknowledgment}

This research was supported by "Study on the interaction between the Cyprus issue and major powers (18ASS008)".

\section{References}

Abdul Rab \& He Zhilong, 2018, SCO, India and Pakistan: New Perspectives and New Hopes, International journal of African and Asian Studies, Vol. 50 (2018)

Baizakova, K. I., 2013,The Shanghai Cooperation Organization's Role in Countering Threats and Challenges to Central Asian Regional Security. Russian Politics \& Law, 51(1), 59-79.

Baogang He., 2018, the Domestic Politics of the Belt and Road Initiative and its Implications, Journal of Contemporary China

Brummer, M., 2007, The Shanghai Cooperation Organization and Iran: a power-full union. Journal of International Affairs, 185-198.

Cabestan, J., 2013, the Shanghai Cooperation Organization, Central Asia, and the Great Powers, an Introduction: One Bed, Different Dreams? Asian Survey, 53(3), 423-435. doi:10.1525/as.2013.53.3.423

Carroll, W. E., 2011, China in the Shanghai Cooperation Organization: Hegemony, Multi-Polar Balance, or Cooperation in Central Asia. International Journal of Humanities and Social Science, 1(19), 1.

China Daily, 2005, Lianyungang Int'l logistics bases lead Belt, Road Initiative development in Jiangsu, http://www.chinadaily.com.cn/regional/2015-05/07/content_20662008.htm,

China Daily, 2015, China Merchants, Summa to build Zarubino Port, 2015-11-19, http://www.chinadaily.com.cn/business/2015-11/19/content_22483523.htm

China Daily, 2015, Russian president backs China's Silk Road proposal, 2015-04-09, http://www.chinadaily.com.cn/world/cn_eu/2015-04/09/content_20033267.htm

China Daily, 2017, Gas pipeline to be ready in 3 years, 2017-12-14, http://europe.chinadaily.com.cn/a/201712/14/WS5a31bd3aa3108bc8c6732110.html 
Dushanbe Declaration, 2014, "DUSHANBE DECLARATION by the Heads of the Member States of the Shanghai Cooperation Organization", September 11 and 12, 2014, http://eng.sectsco.org/documents/

FarkhodAminjonov, 2018, Central Asian Gas Exports Dependency, The RUSI Journal, 163:2, 66-77, DOI: $10.1080 / 03071847.2018 .1470392$

Fei, G., 2010,The Shanghai Cooperation Organization and China's New Diplomacy. Netherlands Institute of International Relations" Clingendael".

Galiia A. Movkebaeva, 2013, Energy Cooperation Among Kazakhstan, Russia, and China Within the Shanghai Cooperation Organization, Russian Politics \& Law, 51:1, 80-87, DOI: 10.2753/RUP1061-1940510105

Ghiasy, R., \& Zhou, J., 2017,The Silk Road Economic Belt. Considering Security Implications and EU-China Cooperation Prospects. Stockholm International Peace Research Institute, 59.

Huasheng, Z. 2013, China's View of and Expectations from the Shanghai Cooperation Organization. Asian Survey, 53(3), 436-460. doi:10.1525/as.2013.53.3.436

Jing-Dong Yuan, 2010, China's Role in Establishing and Building the Shanghai Cooperation Organization (SCO), Journal of Contemporary China, 19:67, 855-869, DOI: 10.1080/10670564.2010.508587

Johannes Feige, 2016, China's Road to Closer Ties with Russia, the diplomat, https://thediplomat.com/2016/08/chinasroad-to-closer-ties-with-russia/

Joint communique, 2003, "JOINT COMMUNIQUÉ Meeting of the Council of Heads of Government (Prime Ministers) of the Shanghai Cooperation Organization”, September 23, 2003, http://eng.sectsco.org/documents/

Joint communique, 2004, "JOINT COMMUNIQUE Meeting of the Council of Heads of Government (Prime Ministers) of the Member States of the Shanghai Cooperation Organization", September 23, 2004, http://eng.sectsco.org/documents/

Library of Congress, 2006, Library of Congress - Federal Research Division, Country Profile: China, August 2006, https://www.loc.gov/rr/frd/cs/profiles/China.pdf

Majid, A., 2016, Shanghai Cooperation Organization: Expanding Horizons of Regional Cooperation. Pakistan Vision, $17(1), 146$.

QIAN, X., 2016, The New Silk Road in West Asia under "the Belt and Road" Initiative. Journal of Middle Eastern and Islamic Studies (in Asia), 10(1), 26-55.

Qingdao declaration, 2018, Qingdao Declaration of the Council of Heads of State of Shanghai Cooperation Organization, 10 June 2018,http://eng.sectsco.org/documents/

Rahman, K., 2011, Central Asia, Energy Security and Shanghai Cooperation Organization. Policy Perspectives, 65-76.

Strategic comments, 2018, the evolution of the Shanghai Cooperation Organization, Strategic Comments, 24:5, vii-ix, DOI: $10.1080 / 13567888.2018 .1495424$

Tashkent Summit, 2010, Declaration of the Tenth Meeting of the Council of Heads of Member States of the Shanghai Cooperation Organization, Tashkent, 11 June 2010, http://eng.sectsco.org/documents/

Tim Summers, 2016, China's 'New Silk Roads': sub-national regions and networks of global political economy, Third World Quarterly, DOI: 10.1080/01436597.2016.1153415

Xinhuanet, 2015, Highlights of proposals for China's 13th Five-Year Plan, 2015-11-04, http://www.xinhuanet.com//english/photo/2015-11/04/c_134783513.htm

Xue Gong, 2018, The Belt \& Road Initiative and China's influence in Southeast Asia, The Pacific Review, DOI: $10.1080 / 09512748.2018 .1513950$

Zhengzhou Summit, 2015, Statement By The Heads Of Government (Prime Minister) Of The Member States Of The Shanghai Cooperation Organization On Regional Economic Cooperation, December 15, 2015, http://eng.sectsco.org/documents/

Zhong Nan \& Jing Shuiyu, 2018, B\&R Initiative key to SCO countries, 2018-06-09, http://usa.chinadaily.com.cn/a/201806/09/WS5b1b6d56a31001b82571f165.html

Zhou, W., \& Esteban, M., 2018, Beyond Balancing: China's approach towards the Belt and Road Initiative. Journal of Contemporary China, 1-15. 